\title{
Infectious agents and xenobiotics in the etiology of primary biliary cirrhosis
}

\author{
Carlo Selmi $^{\mathrm{a}, *}$, Maria De Santis ${ }^{\mathrm{a}}$, Francesca Cavaciocchi ${ }^{\mathrm{a}}$ and M. Eric Gershwin ${ }^{\mathrm{b}}$ \\ ${ }^{a}$ Department of Internal Medicine, IRCCS-Istituto Clinico Humanitas, University of Milan, Italy \\ ${ }^{\mathrm{b}}$ Division of Rheumatology, Allergy, and Clinical Immunology, University of California at Davis, Davis, CA, USA
}

\begin{abstract}
Primary biliary cirrhosis (PBC)is a chronic autoimmune cholestatic liver disease that manifests a latitudinal gradient in prevalence and incidence. The mechanisms leading to the initiation and perpetuation of PBC remain largely enigmatic, although it is established that a combination of genetic predisposition and environmental stimulation is required. PBC is also characterized by a high concordance rate in monozygotic twins and is considered a model autoimmune disease because of several features common to other conditions and the relatively homogeneous serological and biochemical features. From a diagnostic standpoint, $\mathrm{PBC}$ is characterized by the highest specificity of serum autoantibodies directed at mitochondrial proteins. Several risk factors have been suggested to be associated with PBC, including exposure to infectious agents and chemical xenobiotics that will be critically discussed in the present review article.
\end{abstract}

\section{Introduction}

Primary biliary cirrhosis (PBC) is a rare organspecific autoimmune disease characterized by an immune-mediated destruction of small- and mediumsize bile ducts with resulting chronic cholestasis and ultimately liver cirrhosis [1]. One major paradox in $\mathrm{PBC}$ pathogenesis is common to several autoimmune diseases and is based on the observation that, although the autoimmune attack is directed against ubiquitous mitochondrial antigens belonging to the family of 2oxoacid dehydrogenase complexes (2-OADC), the disease specifically involves biliary epithelial cells, i.e. cholangiocytes [2]. Among components of 2-OADC, the E2 subunit of the pyruvate dehydrogenase complex (PDC-E2) constitute the predominant autoantigen recognized by the vast majority of patient sera [3]. As for other autoimmune diseases, genetic and environmental factors are involved in PBC pathogenesis, as well represented in monozygotic twins who fail to demonstrate a complete concordance rate [4] or the reported significant genetic associations encountered in subgroups of

* Corresponding author: Carlo Selmi MD PhD, Department of Internal Medicine, IRCCS Istituto Clinico Humanitas, via A. Manzoni 56, 20089 Rozzano, Milan, Italy. Tel.: +39 028224 5129; Fax: +39 028224 4590, E-mail: carlo.selmi@unimi.it. patients [5]. The immunologic scenario of the disease is based on both the innate and adaptive arms of immunity [6] while the latter includes both humoral and cellular responses [7]. Highly disease-specific serum antimitochondrial autoantibodies (AMA) are directed against components of the 2-oxoacid dehydrogenase complex (2-OADC) and are detected in the vast majority of patients [8]. Similarly, liver infiltrating autoreactive T cells are found in patients with PBC irrespective of their AMA status [9]. These cells recognize antigens overlapping with AMA specificities and are thought to play the major role in biliary cell destruction through direct cytotoxicity (CD8+ cells) and as a result of cytokine production $(\mathrm{CD} 4+)$ [7,10], as well established in liver immunity $[11,12]$.

\section{The immunobiology of the biliary epithelium}

Biliary epithelial cells are actively involved in the peculiar immunity of the liver [13] as they represent a specialized epithelium expressing a plethora of factors contributing to antimicrobial defense. Overall, cholangiocytes represent the first line of defense for the biliary system against microbes derived from the gut through the portal vein and the extrahepatic bile ducts [14], but they are also a possible target of immune mediated in- 
jury as in the cases of $\mathrm{PBC}$, primary sclerosing cholangitis [15], or graft-versus-host liver disease [16], along with autoimmune hepatitis overlap syndromes [17].

Indeed, cholangiocytes express receptors for pathogen-associated molecular pattern (PAMP) represented by the majority of toll like receptors $[18,19]$, cytokines, such as IL-6 and IL-8 [20], chemokines, such as MCP-1 [20], growth factors, such as TGF- $\beta$, CTGF, PDGF, endothelin-1 [19], and immunoactive peptides, such as defensin $\beta$ [21]. Further, cholangiocytes can cross-talk with other immune cells [22] in the liver through the expression of specific adhesion molecules, such as LFA-3 and CD40 [23] and, unlike other epithelial cells, they also feature as antigen presenting cells expressing HLA class II [24-26] and co-stimulatory molecules, such as CD80 and CD86 [23,27]. More pertinent to PBC pathogenesis, biliary epithelial cells are unique in secreting immunoglobulins $\mathrm{A}$ of the secretory type ( $\operatorname{IgA}$ ) through transcytosis in the biliary lumen $[28,29]$ which may in turn cause the organ-specific immune-mediated injury and justify the detection of IgA-AMA in the bile and saliva of patients [30] or the general pro-inflammatory milieu [31].

The mitochondrial antigens recognized by both $\mathrm{B}$ and $\mathrm{T}$ cell autoimmune responses in $\mathrm{PBC}$ are ubiquitously expressed in nucleated cells and highly conserved in phylogenesis [32]. It has been proven that mitochondrial antigens are not cryptic to the immune system and that the immune system is normally tolerant to mitochondrial self-antigens, even if responsive against bacterial homologues. During spontaneous or induced apoptosis, various cell types (virtually all) express mitochondrial antigens on the intact plasma membrane and within the apoptotic blebs $[33,34]$ which are then capable to initiate the immune response by presenting the AMA antigens [35]. This latter process is specific to cholangiocytes and suggests why the disease recurs following liver transplantation [36,37]. Indeed, AMA react, though weakly, against biliary epithelial cells of normal subjects [38], and specific autoreactive $\mathrm{T}$ [39, 40] and B cells, and serum AMA [41] have been found in the serum of non-PBC subjects. Nevertheless, the immune system starts an autoimmune attack against cholangiocytes only in PBC patients and this appears to be irrespective of whether the biliary epithelium is derived from a patient with $\mathrm{PBC}$ or a control subject [42]. Accordingly, liver infiltrating autoreactive T cells were found only in PBC patients [43], irrespective of the AMA status [44]. Genetic predisposition is evoked to explain the breakdown of tolerance to 2-OADC antigens in PBC $[8,45]$ but additional factors are advocat- ed, including the peculiar processing and presentation of antigens within cholangiocytes and the occurrence of an environmental trigger which represents the major issue to be discussed in the present article.

Mitochondrial antigens undergo cell-specific processing that are thought to contribute to PBC organ specificity $[46,47]$. Of seminal importance is the observation that the lysine-lipoylated domains (common immunogenic core of 2-OADC autoantigens, including PDC-E2) derived from cholangiocytes retain their immunogenicity following apoptosis [48]. The lack of putative post-translational modifications alters protein degradation leading to the accumulation and exposure of a great amount of self-reactive antigens, as hypothesized in other organ-specific autoimmune diseases [49].

As previously stated, the AMA immunodominant epitope is represented by the inner lipoylated domain of PDC-E2 while other epitopes are localized within the outer lipoylated domain of the same complex, the E2 subunit of the branched chain 2-oxoacid dehydrogenase complex (BCOADC-E2), and the E2 subunit of the 2-oxoglutarate dehydrogenase [50] complex (OGDCE2). They all share a common motif in the N-terminal region containing lysine-lipoylated domains [47]. In most cell types lysine-lipoylated sequences are oxidized by glutathiones when released from mitochondria during apoptosis [46] as the oxidated forms are not immunogenic and are not recognized by serum AMA as the glutathionylation masks the autoantibody recognition site [46] via potential mechanisms [51]. Conversely, cholangiocytes and cells from other epithelia fail to covalently link glutathione to lysine-lipoyl groups during apoptosis [46] with consequent accumulation and exposure of potentially self-reactive antigens as the reduced forms of PDC-E2 fail to undergo normal protease degradation. In cholangiocytes the cleavage of the immunodominant PDC-E2 epitope has not been detected in vivo either during apoptosis $[46,48]$ or during phagocytosis [52]. Moreover, some authors reported an enhanced expression of 2-OADC proteins, with particular luminal concentration, in cholangiocytes from patients with PBC compared to healthy subjects and patients with other chronic inflammatory biliary disease such as primary sclerosing cholangitis [38]. This abnormal expression can be explained by different mechanisms; one possibility is that self-antigens are presented by cholangiocytes complexed to HLA molecules. Nevertheless, HLA class II have a prevalent intrahepatic basolateral, rather than luminal, surface expression on cholangiocytes [24-27,53] and are weakly expressed in the early stages of disease [27]. Different hypotheses 
state that self-antigens are exposed on the cell membrane during cholangiocyte apoptosis $[33,46]$ or during the rearrangement of lipid rafts as seen after toll like receptor activation by microbe infection [54] or after the ingestion of apoptotic cholangiocytes by other cholangiocytes [52]. Cholangiocyte phagocytosis of neighboring apoptotic cholangiocytes is not specific to PBC, being observed in vitro in cultured cholangiocyte lines and in other chronic liver diseases, but it has been suggested that this phenomenon can be involved in the presenting process of mitochondrial antigen observed in PBC.

\section{The epidemiology of PBC suggests a crucial role for the environment}

Studying the epidemiology of complex diseases is commonly utilized as a proof of concept to determine the impact of the environment on their development, although these observations rarely lead to the identification of specific factors. In the case of PBC, it has been observed that prevalence and incidence rates are higher in Northern European countries (particularly the United Kingdom and Scandinavian countries) and the Northern United States (Minnesota) compared to other areas such as Mediterranean countries. However, these observations might be the result of different methodologies for case finding in epidemiological studies, rather than reflect a true difference in the prevalence of cases and, similar to clusters [55], could ultimately be anecdotal. More importantly, no solid population-based study has been proposed thus far and all estimates are based on the identification of cases already diagnosed [56]. This is in part due to the lack of a sensitive non-invasive marker of disease with the exception of serum AMA which, may appear decades before the disease and cannot ben detected in up to $10 \%$ of PBC cases. It has also been hypothesized that the incidence of PBC in the developed world might be increasing, but this hypothesis is potentially burdened by additional types of bias as observed in other conditions [57]. Finally, it should be noted that populationbased studies on PBC must necessarily rely on AMA detection using indirect immunofluorescence, an assay that fails to determine antibody positivity in up to $15 \%$ of PBC cases. Following numerous studies in which $\mathrm{PBC}$ incidence and prevalence have been addressed in different populations, more recent data were reported to support a possible role for genetics as well as environmental factors in determining disease susceptibility, as supported by increasing incidence rates. Once again, however, the impact of an increased disease awareness among physicians and of the more widespread use of AMA determination cannot be overlooked when comparing different time frames. A population-based study performed in Australia has identified 84 cases of PBC from the region of Victoria using rigorous case-finding methods that included all three major diagnostic criteria and reported a PBC prevalence of 19.1 per million, among the lowest rates ever reported [58]. However, a subsequent study from the same region reported different data on 249 cases with a cumulative incidence almost 10-fold higher than that reported earlier [59]. Importantly, prevalence rates were significantly higher for British, Italian, and Greek immigrants, compared to the Victorian-born population (which clearly recognizes a British background in most cases) thus implying the importance of environmental priming possibly occurring early in life. In the United States, a large study performed on the population of Olmsted county, Minnesota [60] estimated the age- and sex-adjusted PBC prevalence to be 27 per million, among the highest ever reported, and the calculation was based on data from a computerized State index of diagnoses for inpatients and outpatients. Data from Canada have provided intriguing observations on subjects from British Columbia of Native Canadian ancestry for whom PBC has strikingly high prevalence and incidence rates [61]. Whether these ethnic differences reflect solely the effects of genetics or include a role for migratory fluxes still needs to be determined while anecdotal data are fascinating in suggesting that pollutants may enhance the incidence of PBC in specific areas [62]. The role of genetics in PBC appears well established, yet data from association studies in candidate genes including human leukocyte antigens [63] have been inconclusive or limited to specific geographical areas [56] and a genome-wide study is awaited [64].

Identifying risk factors is a critical challenge in directing experimental research, particularly when searching for environmental factors. Familial history and genetic predisposition are by far the most convincing risk factors identified for PBC. However, several non genetic factors have also been proposed to play a role. Our group recently concluded the largest epidemiological study reported thus far which included 1032 patients from 20 Tertiary Referral Centers in the US representative of all but two States [65]. A similar number of controls were matched to cases for sex, age, and geographical origin (using the random-digit dialing matching system) and we utilized a survey based 
on over 180 standardized questions, including subquestions, investigating demographics, personal and family medical history, reproductive history, and lifestyle factors [66]. The multivariate analysis demonstrated that having a first-degree relative with PBC, a history of recurrent urinary tract infections, past smoking, or the use of hormone replacement therapies are significantly associated with an increased risk of having PBC [65]. The frequent use of nail polish also slightly increased the risk of having PBC. A potentially confounding factor in this study was that patients with PBC had a significantly higher family income compared to controls suggesting a role for a better quality of healthcare. Nevertheless, the proposed association were most recently independently confirmed [67].

\section{Environmental agents in PBC onset}

As previously illustrated, cell type-specific differences in apoptosis and phagocytosis of apoptotic cells seem to contribute to tissue-specific damage in $\mathrm{PBC}$ rather than to the breakdown of tolerance to 2-OADC antigens [68] and should thus be considered mechanisms for injury perpetuation rather than initiation. To this regard, environmental factors, such as chemical compounds and/or infectious agents are more likely involved into the breakdown of tolerance through molecular mimicry and cross reactivity mechanisms [69]. This is well supported by the incomplete concordance rate for $\mathrm{PBC}$ in monozygotic twins [4] and more generally by the epigenetic differences in healthy monozygotic twins sharing different durations of environmental stimuli [70] that have already been advocated for other autoimmune diseases [71] through different mechanisms [72,73]. A mimotope carried by a microbe or a neo-antigen generated by xenobiotic-modified selfantigen mimicking mitochondrial proteins may activate autoreactive lymphocytes. Then, the process could become self-perpetuating because of the presence of cross reactive unmodified self-antigens on cholangiocytes surface.

PDC-E2 specific autoantibodies and autoreactive CD4+ and CD8 + T cells recognize different overlapping or close epitopes [41,74-77]. These self-epitopes are well-conserved sequences among species with a high degree of similarity between human and microbial sequences. As a result, molecular mimicry between human and microbial epitopes is the base of the cross recognition by $\mathrm{B}$ and $\mathrm{T}$ cells of microbial proteins by
PBC sera that has been repeatedly proposed to support molecular mimicry [78].

Different from other conditions [79], the pathogenetic role of serum AMA is still debated and a recent report has questioned the sequence of the immunodominant $B$ cell epitope and the role of the lysine-lypoilated motif in the PBC B cell response [77], the study of the immunodominant $T$ cell epitope, PDC-E2 163-176, has provided evidence crucial to PBC pathogenesis [40]. This can be summarized in one unifying hypothesis. Based on the reactivity of cloned PDC-E2 163-176specific $\mathrm{T}$ cell lines, it has been demonstrated that the contact residues with $\mathrm{T}$ cell receptors (TCRs) are ${ }^{168} \mathrm{EIExDK}^{173}$ and that microbial proteins, whether related to PDC-E2 or not, that have an ExDK sequence can undergo cross recognition by autoreactive $\mathrm{T}$ cells. Interestingly, the PDC-E2 peptide was not lipoylated in $\mathrm{K}^{173}$ and conservative substitutions in this position did not abrogate $\mathrm{T}$ cell response thus suggesting a minor role of the lysine-lipoylated group in $\mathrm{T}$ cell recognition. Moreover, $\mathrm{E}^{170}$ is crucial to $\mathrm{T}$ cell recognition as no substitution was allowed without abrogating the immunoreactivity, possibly secondary to the fact that the CDR3 motif used by TCRs to contact the negative charged glutamic acid ( $\left.\mathrm{E}^{170}\right)$ is RGxG or G,S, and/or R i.e. a sequence containing the positive charged arginine (R). These results are of particular relevance considering the proximity of $\mathrm{E}^{170}$ to $\mathrm{K}^{173}$ and we hypothesize that the glutathionylation of the lysine-lipoyl residue in position 170 can mask or alter the exposure of $E^{170}$ thus abolishing the critical contact residue with CDR3. This mechanism is an immunologic defense in all cell type but cholangiocytes where the reduced form of the group can favor the TCR recognition of the epitope and the role of lipoic acid per se requires further studies [80].

\section{Infectious agents: Numerous studies, limited evidence}

Epidemiology suggests an involvement of an external trigger in PBC. The diagnosis of $\mathrm{PBC}$ at the same time or within a short period of time among members of the same family [81], the reported cases of non familial clustering [55,62,82], and the concordance rates among monozygotic twins [4] suggest the need for a common environmental factor. Moreover, it has been described a changing risk of $\mathrm{PBC}$ in subjects moving from areas with high risk of $\mathrm{PBC}$ to areas with lower risk and vice versa [58,83]. As with other autoimmune diseases, infectious agents have been implicated as pu- 
tative triggers in the induction and/or maintenance of PBC. To further support this hypothesis it has been reported that lipopolysaccharide (LPS), a specific component of gram negative bacteria cellular wall, alone or in combination with PDC-E2, can induce portal lymphocyte infiltration and cholangiocyte degeneration mimicking PBC in mice. On the other hand, lipoteichoic acid (LTA), the gram positive cell wall component, has been detected in PBC liver samples around damaged bile ducts and LTA-specific IgA titer has been found to be significantly higher in sera from patients with PBC compared to healthy subjects [84]. In addition, it has been reported that bacterial DNA,containing unmethylated CpG motifs, could trigger PDC-specific Th1 response in mice immunized with PDC [85]. Recently, Th17 cells, i.e. components of mucosal host defense system against infections, but also involved in the pathogenesis of other autoimmune diseases [86], have been found around bile ducts in PBC $[87,88]$. However, the identity of the pathogen and the exact mechanism potentially triggering the disease remain to be determined despite the large number of studies who attempted to address the issue.

Several mechanisms have been proposed to explain how an infectious agent may trigger or contribute to perpetuate an autoimmune disease in susceptible subjects. Molecular mimicry is by far the most studied having been reported for many microbes [89]. In fact, shared sequences between human and microbial proteins can break the immune tolerance to self proteins by inducing cross reactive antibodies or cross recognition by effector T cells. Moreover, molecular mimicry can lead to epitope spreading accelerating or perpetuating the autoimmune process [90], a phenomenon which has been repeatedly disproven in PBC. Pathogens can also stimulate autoreactive lymphocytes through bystander activation. The release of self-antigens from damaged cells together with microbial antigens (mitochondrial related and unrelated proteins, LPS, LTA) and DNA (unmethylated $\mathrm{CpG}$ motifs) causes hyperactivation of antigen presenting cells and innate immune system cells [91] leading to over-processing of self-mimicking microbial antigens and enhanced cytokine production with consequent immune complex formation and expansion of autoreactive cells [92], similar to other experimental settings [93]. Other non-exclusive mechanisms involve superantigen polyclonal activation of $\mathrm{T}$ cells, i.e. staphylococcal enterotoxins [94], mouse mammary tumor virus antigens [95] and viral polyclonal activation of B cells, i.e. Epstein Barr virus [96], IgA production, and Th17 differentiation. Of particular interest is the role of $\operatorname{IgA}$ which represents the major class of antibodies produced in the mucosal immune system of gastrointestinal and respiratory tract as defense against microbes entering by these routes. Cholangiocytes, having the unique role of secreting $\operatorname{IgA}$ into bile through transcytosis, are exposed to $\mathrm{IgA}$ antimitochondrial antibodies. It has been experimentally demonstrated that PDC-E2-specific dimeric IgA during transcytosis can activate caspases leading to cholangiocyte apoptosis and contributing to bile duct damage in PBC [48]. In a different fashion, Th17 cells are essential for effective microbial host defense against extracellular bacteria and fungi; moreover, Th17 contribute to virus persistence and chronic inflammation during parasite infections [97], but also to the balance between microbial defense and immune diseases in concert with Treg. It has been suggested that Th17, eventually differentiating after liver microbial exposure, could contribute to the Th1 shift observed in PBC [86-88] along with the defect of T regulatory cells [98] which resembles data from other clinical settings [99].

Numerous specific agents, mainly bacteria, but also viruses, parasites, and fungi, have been investigated as possible agents involved in PBC (recapitulated in Table 1), but most of the studies failed to demonstrate a clear association of a microbial agent with the disease and reported only circumstantial evidence that could not be independently recapitulated. Indeed, most studies supporting the role of infectious agents in the pathogenesis of PBC are based on the linear or conformational mimicry between microbial proteins and human mitochondrial antigens. Notwithstanding a substantial shared sequence homology, in a fewer cases a cross reactivity by 2-OADC-specific autoantibodies and/or $\mathrm{T}$ cells has been also demonstrated. This is the case for Escherichia coli [100,101,103], Novosphingobium aromaticivorans [32,104,105], Salmonella Minnesota [106], Pseudomonas aeruginosa [107], Haemophilus influenzae [103], Yersinia enterocolitica [103], Streptococcus intermedius [108], Lactobacillus delbrueckii [109], Paracoccus denitrificans [110], Mycoplasma [111,112], Mycobacterium gordonae [113], Borrelia burgdorferi [114], Trypanosomes [115], and Ascaridia galli [115] (Table 1). Moreover, microbial antigens or DNA have been found in liver specimens, gallbladder bile, and fecal samples of patients with $\mathrm{PBC}$ as for $N$. aromaticivorans [104], Propionibacterium acnes [116], and Epstein Barr virus [117]. It should be note, however, that these findings were not limited to patients with PBC thus supporting the major role of individual susceptibil- 
Table 1

Infectious agents proposed for PBC etiology and the putative evidence available in the literature

\begin{tabular}{|c|c|c|c|}
\hline $\begin{array}{l}\text { Infectious } \\
\text { agents }\end{array}$ & & Proposed evidence & References \\
\hline \multirow[t]{8}{*}{$\begin{array}{l}\text { Gram negative } \\
\text { bacteria }\end{array}$} & Escherichia coli & $\begin{array}{l}\text { higher frequency of urinary tract infections in patients with PBC } \\
\text { presence of anti-bacterial proteins Ab in PBC pts sera } \\
\text { molecular mimicry with Ab and CD } 4 \text { cross reactivity between bacterial mito- } \\
\text { chondrial homologous proteins and non mitochondrial proteins and PDC-E2 } \\
21-226 \text { and } 163-176\end{array}$ & {$[40,100-103]$} \\
\hline & $\begin{array}{l}\text { Salmonella } \\
\text { minnesota mutant }\end{array}$ & Ab cross recognition between mitochondrial antigens and bacterial peptides & {$[106]$} \\
\hline & $\begin{array}{l}\text { Salmonella } \\
\text { typhimurium }\end{array}$ & $\begin{array}{l}\text { molecular mimicry between product of mutB gene and gp } 210 \text { recognized by } \\
\text { PBC pts Ab }\end{array}$ & {$[100]$} \\
\hline & $\begin{array}{l}\text { Novosphingobium } \\
\text { aromaticivorans }\end{array}$ & $\begin{array}{l}\text { molecular mimicry and Ab cross reactivity between lipoylated microbial pro- } \\
\text { teins and PDC-E2 208- } 237 \\
\text { autoreactive AMA and chronic T cell-mediated cholangiopathy in a murine } \\
\text { model of PBC }\end{array}$ & {$[32,104,105,118]$} \\
\hline & $\begin{array}{l}\text { Helicobacter } \\
\text { pylori }\end{array}$ & $\begin{array}{l}\text { molecular mimicry but not } \mathrm{Ab} \text { or CD } 4 \text { TCR cross recognition between urease } \\
\text { beta and PDC-E } 212-226 \\
\text { exposure of experimental animals to helicobacter species is able to induce } \\
\text { hepatobiliary pathology }\end{array}$ & {$[119,155]$} \\
\hline & $\begin{array}{l}\text { Pseudomonas } \\
\text { aeruginosa }\end{array}$ & $\begin{array}{l}\text { molecular mimicry and CD8 TCR cross recognition between diaminopimelate } \\
\text { decarboxylase and PDC-E2 159-167 }\end{array}$ & [107] \\
\hline & $\begin{array}{l}\text { Haemophilus } \\
\text { influenzae }\end{array}$ & $\begin{array}{l}\text { molecular mimicry and Ab cross reactivity between caseinolytic proteases } \mathrm{P} \\
\text { and PDC-E2 212-226 }\end{array}$ & {$[103]$} \\
\hline & $\begin{array}{l}\text { Yerisinia } \\
\text { enterocolitica }\end{array}$ & $\begin{array}{l}\text { molecular mimicry and Ab cross reactivity between caseinolytic proteases } \mathrm{P} \\
\text { and PDC-E2 212-226 }\end{array}$ & [103] \\
\hline \multirow[t]{4}{*}{$\begin{array}{l}\text { Gram positive } \\
\text { bacteria }\end{array}$} & $\begin{array}{l}\text { Streptococcus } \\
\text { intermedius }\end{array}$ & $\begin{array}{l}\text { high anti-bacterial histone-like DNA-binding protein titers and cross reactivity } \\
\text { against BECs cytoplasmic proteins }\end{array}$ & {$[108]$} \\
\hline & $\begin{array}{l}\text { Lactobacillus } \\
\text { delbrueckii }\end{array}$ & $\begin{array}{l}\text { molecular mimicry and Ab cross recognition between beta galactosidase and } \\
\text { PDC-E2 212-226 }\end{array}$ & [109] \\
\hline & $\begin{array}{l}\text { Propionibacterium } \\
\text { acnes }\end{array}$ & DNA in liver granulomas & {$[116]$} \\
\hline & $\begin{array}{l}\text { Paracoccus } \\
\text { denitrificans }\end{array}$ & cross reactive $\mathrm{Ab}$ with bacterial membrane vesicles & {$[110]$} \\
\hline \multirow[t]{4}{*}{$\begin{array}{l}\text { Intracellular } \\
\text { bacteria }\end{array}$} & $\begin{array}{l}\text { Chlamydia } \\
\text { pneumoniae }\end{array}$ & $\begin{array}{l}\text { presence of anti-chlamydia } \mathrm{Ab} \text { in } \mathrm{PBC} \text { sera but not specific antigens or DNA } \\
\text { in PBC liver samples }\end{array}$ & {$[156]$} \\
\hline & $\begin{array}{l}\text { Mycoplasma } \\
\text { pneumoniae }\end{array}$ & molecular mimicry and Ab cross reactivity between microbial and human PDC & {$[112]$} \\
\hline & $\begin{array}{l}\text { Mycoplasma } \\
\text { gallisepticum }\end{array}$ & molecular mimicry between bacterial surface molecules and PDC-E2 & [111] \\
\hline & $\begin{array}{l}\text { Mycobacterium } \\
\text { gordonae }\end{array}$ & $\begin{array}{l}\text { molecular mimicry and Ab cross reactivity between microbial hsp65 and PDC- } \\
\text { E2 212-226 but not mycobacterial DNA in PBC liver granulomas }\end{array}$ & {$[113,157]$} \\
\hline Spirochetes & $\begin{array}{l}\text { Borrelia } \\
\text { burgdorferi }\end{array}$ & $\begin{array}{l}\text { molecular mimicry and Ab cross recognition between bacterial p41 flagellin } \\
\text { and PDC-E2 208-235 }\end{array}$ & [114] \\
\hline \multirow[t]{2}{*}{ Parasites } & Trypanosomes & $\begin{array}{l}\text { molecular mimicry and } \mathrm{Ab} \text { cross reactivity between parasitic and human mito- } \\
\text { chondrial antigens }\end{array}$ & {$[115]$} \\
\hline & Ascaridia galli & $\begin{array}{l}\text { molecular mimicry and } \mathrm{Ab} \text { cross reactivity between parasitic and human mito- } \\
\text { chondrial antigens }\end{array}$ & {$[115]$} \\
\hline Fungi & $\begin{array}{l}\text { Saccharomyces } \\
\text { cerevisiae }\end{array}$ & high frequency of anti-saccharomyces cerevisiae $\mathrm{Ab}$ in $\mathrm{PBC}$ sera & {$[158]$} \\
\hline \multirow[t]{2}{*}{ Viruses } & $\begin{array}{l}\text { Mouse mammary } \\
\text { tumor virus }\end{array}$ & $\begin{array}{l}\text { questioned molecular mimicry between viral proteins and mitochondrial } \\
\text { antigens }\end{array}$ & {$[159,160]$} \\
\hline & $\begin{array}{l}\text { Epstein Barr } \\
\text { virus }\end{array}$ & high frequency of viral DNA in PBMCs, liver and saliva of PBC cases & {$[117]$} \\
\hline
\end{tabular}

ity in the presence of a common trigger. In a few cases an autoimmune cholangiopathy has been mimicked in animal models after bacterial components exposure as in the most recent case of $N$. aromaticivorans [118] or the less convincing Helicobacter pylori [119]. Taken together these studies suggest that multiple agents and multiple mechanisms could be involved in the pathogenesis of PBC. Interestingly, among microbial pathogens $N$. aromaticivorans is supported by the most solid data, considering also its ability to metabolize halogenated compounds [32,104,105,118]. 


\section{Chemical compounds}

A different environmental factor proposed to trigger disease onset is constituted by foreign chemicals (i.e. xenobiotics) that can either alter or complex to a defined self or non-self protein, causing a change in its molecular structure that induces an immune response. This fascinating hypothesis has been proposed for numerous autoimmune diseases, particularly based on the observed geoepidemiological gradient $[50,120,121]$ in which definitive confirmation is awaited and should not be considered as exclusive with regard to the role of infectious agents. The hypothesis is supported by a number of epidemiology studies, as previously discussed, as well as by the appearance of autoantibodies in subjects immunized with halothane, an inhalatory anesthetic no longer used, with antibodies crossreacting with lipoylated PDC-E2 [122]. As previously stated, lipoic acid is attached to a limited number of proteins, yet it is a critical component of the PDC-E2 epitope [80]. The PDC-E2 structure exposes lipoic acid at the exterior of the protein complex making it accessible to chemical modification [123]. The role of xenobiotics in PBC is supported by serum reactivity against specific organic compounds with structures similar to lipoic acid [124]; further, two of these compounds (6-bromohexanoate and 2-octynoic acid) are capable of inducing AMA and $\mathrm{PBC}$-like liver lesions in guinea pigs [125] and NOD.1101 [126] or C57BL/6 [127] mice, respectively. The ability of $N$. aromaticivorans to metabolize chemical compounds might link xenobiotics and bacteria in the etiology of $\mathrm{PBC}$, as discussed in the previous paragraph.

The 2-OADC antigens undergo several posttranslational modifications endogenously, and such changes may alter the epitope regions of the proteins. Nevertheless, external influences can also contribute to protein alterations and neo-antigen formation [47]. Of note, the liver is constantly exposed to chemicals derived from the gut through the portal circulation to be metabolized, activated, or excreted in the bile. It has been reported that xenobiotics can either alter or complex mitochondrial proteins. In 2001, Long and colleagues first demonstrated that specific organic structures attached to the mitochondrial antigens were recognized by PBC sera with a higher affinity than the native forms of such antigens [128] and indicated that an organic compound may serve as a mimotope for an autoantigen. This provided further evidence for a potential mechanism by which environmental organic compounds can cause PBC. One such halogenated compounds has been shown to induce AMA production in rabbits without requiring the peptide backbone of PDC-E2 [129] but failed to produce liver lesions (possibly in agreement with observations in humans where AMA is present several years prior to the appearance of liver injury) and disappeared when the stimulus was discontinued [130]. A different approach reported the induction of $\mathrm{PBC}$-like liver lesions following longer follow-ups in guinea pigs [125] while a further study reported two new xenobiotic-induced PBC murine models based on the immunization with 2-octynoic acid of NOD.1101 [126] or C57BL/6 [127] mice. These two most recent models share the breakdown of tolerance in the absence of PDC-E2 molecules but fail to manifest the progression to liver cirrhosis. Utilizing a different approach, our group also demonstrated that 2-nonynoic acid is capable of being recognized by PBC sera with high affinity [124]. This is particularly interesting since this non-naturally occurring compound is known to be found in several cosmetic products (including specific nail polish products) and could contribute to the association of PBC with their frequent use $[65,67]$ or possibly the female predominance of the disease [131]. Regarding this issue, several sex-related factors appear to increase the risk of PBC, mostly by means of reproductive life variables. Among these are the role of pregnancies [132], contraceptives, estrogen replacement treatments [65], and recurrent vaginitis [133] but the data provided thus far are inconclusive and the mechanisms remain to be clearly defined. However, the novel hypothesis of sex chromosome-related effects on PBC appears promising [134], and may possibly operate via gene dosage or epigenetic changes [135] which appear to be common to autoimmunity in general [136-139].

\section{Conclusions and future views}

Currently available data on the pathogenesis and epidemiology of PBC support the role of environmental triggers but fails to identify specific agents that are causative of disease onset. Indeed, while geoepidemiology warrants further investigation [140-145], identified risk factors and experimental data appear to point in the same directions and support a role for infectious agents and/or xenobiotics. However, we cannot rule out that what is currently thought to be caused by an agent found in the environment is in fact a result of epigenetic changes, as suggested in other autoimmune diseases [146]. Similarly, the study of innate immunity, as supported by data in other autoimmune condi- 
tions [147] is expected to provide crucial evidence to complete the scenario. Ultimately, over the past few years several animals models have been proposed for $\mathrm{PBC}$, in some cases based on genetic defects [148], in others on specific immunizations $[149,150]$. It will therefore be necessary for future efforts to gather the available models and unite their major strengths into a single comprehensive model. The development of such a model will allow us to overcome the major obstacles to the study of environmental determinants of PBC i.e. the long latency period prior to disease appearance and possibly control additional confounding factors [151] while identifying new therapeutic agents [152-154].

\section{References}

[1] M.E. Gershwin and I.R. Mackay, The causes of primary biliary cirrhosis: Convenient and inconvenient truths, Hepatology 47 (2008), 737-745.

[2] M.E. Gershwin, A.A. Ansari, I.R. Mackay, Y. Nakanuma, A. Nishio, M.J. Rowley and R.L. Coppel, Primary biliary cirrhosis: An orchestrated immune response against epithelial cells, Immunol Rev 174 (2000), 210-225.

[3] M.E. Gershwin, I.R. Mackay, A. Sturgess and R.L. Coppel, Identification and specificity of a cdna encoding the $70 \mathrm{kd} \mathrm{mi-}$ tochondrial antigen recognized in primary biliary cirrhosis, J Immunol 138 (1987), 3525-3531.

[4] C. Selmi, M.J. Mayo, N. Bach, H. Ishibashi, P. Invernizzi, R.G. Gish, S.C. Gordon, H.I. Wright, B. Zweiban, M. Podda and M.E. Gershwin, Primary biliary cirrhosis in monozygotic and dizygotic twins: Genetics, epigenetics, and environment, Gastroenterology 127 (2004), 485-492.

[5] G.M. Hirschfield, X. Liu, C. Xu, Y. Lu, G. Xie, X. Gu, E.J. Walker, K. Jing, B.D. Juran, A.L. Mason, R.P. Myers, K.M. Peltekian, C.N. Ghent, C. Coltescu, E.J. Atkinson, E.J. Heathcote, K.N. Lazaridis, C.I. Amos and K.A. Siminovitch, Primary biliary cirrhosis associated with hla, il12a, and il12rb2 variants, N Engl J Med 360 (2009), 2544-2555.

[6] C. Selmi, A. Lleo, S. Pasini, M. Zuin and M.E. Gershwin, Innate immunity and primary biliary cirrhosis, Curr Mol Med 9 (2009), 45-51.

[7] H. Ishibashi, M. Nakamura, A. Komori, K. Migita and S. Shimoda, Liver architecture, cell function, and disease, Semin Immunopathol 31 (2009), 399-409.

[8] C. Selmi, M. Zuin and M.E. Gershwin, The unfinished business of primary biliary cirrhosis, J Hepatol 49 (2008), 451460.

[9] C. Selmi, M. Zuin, C.L. Bowlus and M.E. Gershwin, Antimitochondrial antibody-negative primary biliary cirrhosis, Clin Liver Dis 12 (2008), 173-185, ix.

[10] P. Invernizzi, C. Selmi and M.E. Gershwin, Update on primary biliary cirrhosis, Dig Liver Dis 42 (2010), 401-408.

[11] L.E. Holz, A. Warren, D.G. Le Couteur, D.G. Bowen and P. Bertolino, Cd8 $+\mathrm{t}$ cell tolerance following antigen recognition on hepatocytes, J Autoimmun 34 (2010), 15-22.

[12] A. Carambia and J. Herkel, Cd4 t cells in hepatic immune tolerance, J Autoimmun 34 (2010), 23-28.

[13] Y.H. Chuang, R.Y. Lan and M.E. Gershwin, The immunopathology of human biliary cell epithelium, Semin Immunopathol 31 (2009), 323-331.
[14] N. Corazza, A. Badmann and C. Lauer, Immune cellmediated liver injury, Semin Immunopathol 31 (2009), 267277.

[15] J.H. Aron and C.L. Bowlus, The immunobiology of primary sclerosing cholangitis, Semin Immunopathol 31 (2009), 383397.

[16] Y. Ichiki, C.L. Bowlus, S. Shimoda, H. Ishibashi, J.M. Vierling and M.E. Gershwin, T cell immunity and graft-versushost disease (gvhd), Autoimmun Rev 5 (2006), 1-9.

[17] M.S. Longhi, Y. Ma, G. Mieli-Vergani and D. Vergani. Aetiopathogenesis of autoimmune hepatitis, J Autoimmun 34 (2010), 7-14.

[18] X.M. Chen, S.P. O'Hara, J.B. Nelson, P.L. Splinter, A.J. Small, P.S. Tietz, A.H. Limper and N.F. LaRusso, Multiple tlrs are expressed in human cholangiocytes and mediate host epithelial defense responses to cryptosporidium parvum via activation of nf-kappab, J Immunol 175 (2005), 7447-7456.

[19] X.M. Chen, S.P. O'Hara and N.F. LaRusso, The immunobiology of cholangiocytes, Immunol Cell Biol 86 (2008), 497505.

[20] G. Fava, S. Glaser, H. Francis and G. Alpini, The immunophysiology of biliary epithelium, Semin Liver Dis 25 (2005), 251-264.

[21] K. Harada, K. Ohba, S. Ozaki, K. Isse, T. Hirayama, A. Wada and Y. Nakanuma, Peptide antibiotic human beta-defensin-1 and -2 contribute to antimicrobial defense of the intrahepatic biliary tree, Hepatology 40 (2004), 925-932.

[22] C. Selmi, I.R. Mackay and M.E. Gershwin, The immunological milieu of the liver, Semin Liver Dis 27 (2007), 129-139.

[23] M.P. Leon, M.F. Bassendine, P. Gibbs, M. Thick and J.A. Kirby, Immunogenicity of biliary epithelium: Study of the adhesive interaction with lymphocytes, Gastroenterology 112 (1997), 968-977.

[24] G. Ballardini, R. Mirakian, F.B. Bianchi, E. Pisi, D. Doniach and G.F. Bottazzo, Aberrant expression of hla-dr antigens on bileduct epithelium in primary biliary cirrhosis: Relevance to pathogenesis, Lancet 2 (1984), 1009-1013.

[25] J.J. Van den Oord, R. Sciot and V.J. Desmet, Expression of mhc products by normal and abnormal bile duct epithelium, J Hepatol 3 (1986), 310-317.

[26] R.C. Ayres, J.M. Neuberger, J. Shaw, R. Joplin and D.H. Adams, Intercellular adhesion molecule-1 and mhc antigens on human intrahepatic bile duct cells: Effect of proinflammatory cytokines, Gut 34 (1993), 1245-1249.

[27] K. Tsuneyama, J. Van de Water, P.S. Leung, S. Cha, Y. Nakanuma, M. Kaplan, R. De Lellis, R. Coppel, A. Ansari and M.E. Gershwin, Abnormal expression of the e 2 component of the pyruvate dehydrogenase complex on the luminal surface of biliary epithelium occurs before major histocompatibility complex class ii and bb1/b7 expression, Hepatology 21 (1995), 1031-1037.

[28] S. Sakisaka, K. Gondo, M. Yoshitake, M. Harada, M. Sata, K. Kobayashi and K. Tanikawa, Functional differences between hepatocytes and biliary epithelial cells in handling polymeric immunoglobulin a2 in humans, rats, and guinea pigs, Hepatology 24 (1996), 398-406.

[29] N. Fukushima, G. Nalbandian, J. Van De Water, K. White, A.A. Ansari, P. Leung, T. Kenny, S.G. Kamita, B.D. Hammock, R.L. Coppel, F. Stevenson, H. Ishibashi and M.E. Gershwin, Characterization of recombinant monoclonal iga anti-pdc-e2 autoantibodies derived from patients with pbc, Hepatology 36 (2002), 1383-1392.

[30] A. Tanaka, S. Nezu, S. Uegaki, M. Mikami, S. Okuyama, N. Kawamura, M. Aiso, M.E. Gershwin, S. Takahashi, C. Sel- 
mi and $\mathrm{H}$. Takikawa, The clinical significance of iga antimitochondrial antibodies in sera and saliva in primary biliary cirrhosis, Ann N Y Acad Sci 1107 (2007), 259-270.

[31] V. Barak, C. Selmi, M. Schlesinger, M. Blank, N. AgmonLevin, I. Kalickman, M.E. Gershwin and Y. Shoenfeld, Serum inflammatory cytokines, complement components, and soluble interleukin 2 receptor in primary biliary cirrhosis, J Autoimmun (2009).

[32] K.A. Padgett, C. Selmi, T.P. Kenny, P.S. Leung, D.L. Balkwill, A.A. Ansari, R.L. Coppel and M.E. Gershwin, Phylogenetic and immunological definition of four lipoylated proteins from novosphingobium aromaticivorans, implications for primary biliary cirrhosis, J Autoimmun 24 (2005), 209219.

[33] P. Macdonald, J. Palmer, J.A. Kirby and D.E. Jones, Apoptosis as a mechanism for cell surface expression of the autoantigen pyruvate dehydrogenase complex, Clin Exp Immunol 136 (2004), 559-567.

[34] A. Lleo, C. Selmi, P. Invernizzi, M. Podda, R.L. Coppel, I.R. Mackay, G.J. Gores, A.A. Ansari, J. Van de Water and M.E. Gershwin, Apotopes and the biliary specificity of primary biliary cirrhosis, Hepatology 49 (2009), 871-879.

[35] A. Lleo, C.L. Bowlus, G.X. Yang, P. Invernizzi, M. Podda, J. Van de Water, A.A. Ansari, R.L. Coppel, H.J. Worman, G.J. Gores and M.E. Gershwin. Biliary apotopes and antimitochondrial antibodies activate innate immune responses in primary biliary cirrhosis, Hepatology (2010).

[36] J. Neuberger, Liver transplantation for primary biliary cirrhosis: Indications and risk of recurrence, J Hepatol 39 (2003), 142-148.

[37] D.A. Jacob, U.P. Neumann, M. Bahra, J.M. Langrehr and P. Neuhaus, Liver transplantation for primary biliary cirrhosis: Influence of primary immunosuppression on survival, Transplant Proc 37 (2005), 1691-1692.

[38] S. Cha, P.S. Leung, M.E. Gershwin, M.P. Fletcher, A.A Ansari and R.L. Coppel, Combinatorial autoantibodies to dihydrolipoamide acetyltransferase, the major autoantigen of primary biliary cirrhosis, Proc Natl Acad Sci U SA 90 (1993), 2527-2531.

[39] Y. Ichiki, S. Shimoda, H. Hara, H. Shigematsu, M. Nakamura, K. Hayashida, H. Ishibashi and Y. Niho, Analysis of t-cell receptor beta of the t-cell clones reactive to the human pdc-e2 163-176 peptide in the context of hla-dr53 in patients with primary biliary cirrhosis, Hepatology 26 (1997), 728-733.

[40] H. Shigematsu, S. Shimoda, M. Nakamura, S. Matsushita, Y. Nishimura, N. Sakamoto, Y. Ichiki, Y. Niho, M.E. Gershwin and H. Ishibashi, Fine specificity of t cells reactive to human pdc-e2 163-176 peptide, the immunodominant autoantigen in primary biliary cirrhosis: Implications for molecular mimicry and cross-recognition among mitochondrial autoantigens, Hepatology 32 (2000), 901-909.

[41] Q.Y. Chen, M.J. Rowley and I.R. Mackay, Anti-idiotypic antibodies to anti-pdc-e2 in primary biliary cirrhosis and normal subjects, Hepatology 29 (1999), 624-631.

[42] S. Shimoda, K. Harada, H. Niiro, T. Yoshizumi, Y. Soejima, A. Taketomi, Y. Maehara, K. Tsuneyama, M. Nakamura, A. Komori, K. Migita, Y. Nakanuma, H. Ishibashi, C. Selmi and M.E. Gershwin. Biliary epithelial cells and primary biliary cirrhosis: The role of liver-infiltrating mononuclear cells, Hepatology 47 (2008), 958-965.

[43] A.T. Borchers, S. Shimoda, C. Bowlus, C.L. Keen and M.E. Gershwin, Lymphocyte recruitment and homing to the liver in primary biliary cirrhosis and primary sclerosing cholangitis, Semin Immunopathol 31 (2009), 309-322.
[44] S. Shimoda, H. Miyakawa, M. Nakamura, H. Ishibashi, K. Kikuchi, H. Kita, H. Niiro, Y. Arinobu, N. Ono, I.R. Mackay, M.E. Gershwin and K. Akashi, Cd4 t-cell autoreactivity to the mitochondrial autoantigen pdc-e 2 in ama-negative primary biliary cirrhosis, J Autoimmun 31 (2008), 110-115.

[45] P. Invernizzi and M.E. Gershwin, The genetics of human autoimmune disease, J Autoimmun 33 (2009), 290-299.

[46] J.A. Odin, R.C. Huebert, L. Casciola-Rosen, N.F. LaRusso and A. Rosen, Bcl-2-dependent oxidation of pyruvate dehydrogenase-e2, a primary biliary cirrhosis autoantigen, during apoptosis, J Clin Invest 108 (2001), 223-232.

[47] T.K. Mao, P.A. Davis, J.A. Odin, R.L. Coppel and M.E. Gershwin, Sidechain biology and the immunogenicity of pdc-e2, the major autoantigen of primary biliary cirrhosis, Hepatology 40 (2004), 1241-1248.

[48] S. Matsumura, J. Van De Water, P. Leung, J.A. Odin, K. Yamamoto, G.J. Gores, K. Mostov, A.A. Ansari, R.L. Coppel, Y. Shiratori and M.E. Gershwin, Caspase induction by iga antimitochondrial antibody: Iga-mediated biliary injury in primary biliary cirrhosis, Hepatology 39 (2004), 1415-1422.

[49] E.M. Jacobson, A. Huber and Y. Tomer, The hla gene complex in thyroid autoimmunity: From epidemiology to etiology, J Autoimmun 30 (2008), 58-62.

[50] G.S. Cooper, M.L. Bynum and E.C. Somers, Recent insights in the epidemiology of autoimmune diseases: Improved prevalence estimates and understanding of clustering of diseases, J Autoimmun (2009).

[51] M. Sasaki, H. Ikeda and Y. Nakanuma, Activation of atm signaling pathway is involved in oxidative stress-induced expression of mito-inhibitory $\mathrm{p} 21 \mathrm{waf} 1 / \mathrm{cip} 1$ in chronic nonsuppurative destructive cholangitis in primary biliary cirrhosis: An immunohistochemical study, JAutoimmun 31 (2008), 73-78.

[52] J. Allina, B. Hu, D.M. Sullivan, M.I. Fiel, S.N. Thung, S.F. Bronk, R.C. Huebert, J. van de Water, N.F. LaRusso, M.E. Gershwin, G.J. Gores and J.A. Odin. T cell targeting and phagocytosis of apoptotic biliary epithelial cells in primary biliary cirrhosis, J Autoimmun 27 (2006), 232-241.

[53] H. Nishimoto, G. Yamada, M. Mizuno and T. Tsuji, Immunoelectron microscopic localization of mhe class 1 and 2 antigens on bile duct epithelial cells in patients with primary biliary cirrhosis, Acta Med Okayama 48 (1994), 317-322.

[54] J.B. Nelson, S.P. O'Hara, A.J. Small, P.S. Tietz, A.K. Choudhury, R.E. Pagano, X.M. Chen and N.F. LaRusso, Cryptosporidium parvum infects human cholangiocytes via sphingolipid-enriched membrane microdomains, Cell Microbiol 8 (2006), 1932-1945.

[55] S. Abu-Mouch, C. Selmi, G.D. Benson, T.P. Kenny, P. Invernizzi, M. Zuin, M. Podda, L. Rossaro and M.E. Gershwin, Geographic clusters of primary biliary cirrhosis, Clin Dev Immunol 10 (2003), 127-131.

[56] C. Selmi, P. Invernizzi, M. Zuin, M. Podda and M.E. Gershwin, Genetics and geoepidemiology of primary biliary cirrhosis: Following the footprints to disease etiology, Semin Liver Dis 25 (2005), 265-280.

[57] S. Arber, J. McKinlay, A. Adams, L. Marceau, C. Link and A. O'Donnell, Patient characteristics and inequalities in doctors' diagnostic and management strategies relating to chd: A video-simulation experiment, Soc Sci Med 62 (2006), 103115.

[58] R.G. Watson, P.W. Angus, M. Dewar, B. Goss, R.B. Sewell and R.A. Smallwood, Low prevalence of primary biliary cirrhosis in victoria, australia. Melbourne liver group, Gut 36 (1995), 927-930. 
[59] S. Sood, P.J. Gow, J.M. Christie and P.W. Angus, Epidemiology of primary biliary cirrhosis in victoria, australia: High prevalence in migrant populations, Gastroenterology 127 (2004), 470-475.

[60] W.R. Kim, K.D. Lindor, G.R. Locke, 3rd, T.M. Therneau, H.A. Homburger, K.P. Batts, B.P. Yawn, J.L. Petz, L.J. Melton, 3rd and E.R. Dickson, Epidemiology and natural history of primary biliary cirrhosis in a us community, Gastroenterology 119 (2000), 1631-1636.

[61] L. Arbour, R. Rupps, L. Field, P. Ross, A. Erikson, H. Henderson, W. Hill and E. Yoshida, Characteristics of primary biliary cirrhosis in british columbia's first nations population, Can J Gastroenterol 19 (2005), 305-310.

[62] A. Ala, C.M. Stanca, M. Bu-Ghanim, I. Ahmado, A.D. Branch, T.D. Schiano, J.A. Odin and N. Bach, Increased prevalence of primary biliary cirrhosis near superfund toxic waste sites, Hepatology (Baltimore, Md 43 (2006), 525-531.

[63] P. Invernizzi, C. Selmi, F. Poli, S. Frison, A. Floreani, D. Alvaro, P. Almasio, F. Rosina, M. Marzioni, L. Fabris, L. Muratori, L. Qi, M.F. Seldin, M.E. Gershwin and M. Podda, Human leukocyte antigen polymorphisms in italian primary biliary cirrhosis: A multicenter study of 664 patients and 1992 healthy controls, Hepatology (Baltimore, Md 48 (2008), 1906-1912.

[64] P. Invernizzi and M.E. Gershwin, The genetic basis of primary biliary cirrhosis: Premises, not promises, Gastroenterology 135 (2008), 1044-1047.

[65] M.E. Gershwin, C. Selmi, H.J. Worman, E.B. Gold, M. Watnik, J. Utts, K.D. Lindor, M.M. Kaplan and J.M. Vierling, Risk factors and comorbidities in primary biliary cirrhosis: A controlled interview-based study of 1032 patients, Hepatology 42 (2005), 1194-1202.

[66] A. Parikh-Patel, E.B. Gold, H. Worman, K.E. Krivy and M.E. Gershwin. Risk factors for primary biliary cirrhosis in a cohort of patients from the united states, Hepatology 33 (2001), 16-21.

[67] M.I. Prince, S.J. Ducker and O.F. James, Case-control studies of risk factors for primary biliary cirrhosis in two united kingdom populations, Gut 59 (2010), 508-512.

[68] M.P. Leon, J.A. Kirby, P. Gibbs, A.D. Burt and M.F. Bassendine, Immunogenicity of biliary epithelial cells: Study of the expression of b7 molecules, J Hepatol 22 (1995), 591-595.

[69] C. Selmi, The worldwide gradient of autoimmune conditions, Autoimmun Rev 9 (2010), A247-A250.

[70] M.F. Fraga, E. Ballestar, M.F. Paz, S. Ropero, F. Setien, M.L. Ballestar, D. Heine-Suner, J.C. Cigudosa, M. Urioste, J. Benitez, M. Boix-Chornet, A. Sanchez-Aguilera, C. Ling, E. Carlsson, P. Poulsen, A. Vaag, Z. Stephan, T.D. Spector, Y.Z. Wu, C. Plass and M. Esteller, Epigenetic differences arise during the lifetime of monozygotic twins, Proc Natl Acad Sci U S A 102 (2005), 10604-10609.

[71] Q. Lu, Y. Renaudineau, S. Cha, G. Ilei, W.H. Brooks, C. Selmi, A. Tzioufas, J.O. Pers, S. Bombardieri, M.E. Gershwin, S. Gay and P. Youinou, Epigenetics in autoimmune disorders: Highlights of the 10th sjogren's syndrome symposium, Autoimmun Rev (2010).

[72] M. Dittmar, C. Bischofs, N. Matheis, R. Poppe and G.J. Kahaly, A novel mutation in the dnase 1 gene is related with protein instability and decreased enzyme activity in thyroid autoimmunity, J Autoimmun 32 (2009), 7-13.

[73] K.M. Pauley, S. Cha and E.K. Chan, Microrna in autoimmunity and autoimmune diseases, J Autoimmun 32 (2009), 189-194.
[74] J. Van de Water, M.E. Gershwin, P. Leung, A. Ansari and R.L. Coppel, The autoepitope of the 74-kd mitochondrial autoantigen of primary biliary cirrhosis corresponds to the functional site of dihydrolipoamide acetyltransferase, $J$ Exp Med 167 (1988), 1791-1799.

[75] H. Kita, S. Matsumura, X.S. He, A.A. Ansari, Z.X. Lian, J. Van de Water, R.L. Coppel, M.M. Kaplan and M.E. Gershwin, Quantitative and functional analysis of pdc-e2-specific autoreactive cytotoxic t lymphocytes in primary biliary cirrhosis, J Clin Invest 109 (2002), 1231-1240.

[76] S. Matsumura, H. Kita, X.S. He, A.A. Ansari, Z.X. Lian, J. Van De Water, K. Yamamoto, T. Tsuji, R.L. Coppel, M. Kaplan and M.E. Gershwin, Comprehensive mapping of hlaa0201-restricted cd8 t-cell epitopes on pdc-e2 in primary biliary cirrhosis, Hepatology 36 (2002), 1125-1134.

[77] S. Braun, C. Berg, S. Buck, M. Gregor and R. Klein, Catalytic domain of pdc-e 2 contains epitopes recognized by antimitochondrial antibodies in primary biliary cirrhosis, World $J$ Gastroenterol 16 (2010), 973-981.

[78] S. Shimoda, M. Nakamura, H. Ishibashi, A. Kawano, T. Kamihira, N. Sakamoto, S. Matsushita, A. Tanaka, H.J. Worman, M.E. Gershwin and M. Harada, Molecular mimicry of mitochondrial and nuclear autoantigens in primary biliary cirrhosis, Gastroenterology 124 (2003), 1915-1925.

[79] E. Karnabi, Y. Qu, R. Wadgaonkar, S. Mancarella, Y. Yue, M. Chahine, R.M. Clancy, J.P. Buyon and M. Boutjdir, Congenital heart block: Identification of autoantibody binding site on the extracellular loop (domain i, s5-s6) of alpha(1d) 1-type ca channel, J Autoimmun 34 (2010), 80-86.

[80] S.F. Bruggraber, P.S. Leung, K. Amano, C. Quan, M.J. Kurth, M.H. Nantz, G.D. Benson, J. Van de Water, V. Luketic, T.E. Roche, A.A. Ansari, R.L. Coppel and M.E. Gershwin, Autoreactivity to lipoate and a conjugated form of lipoate in primary biliary cirrhosis, Gastroenterology 125 (2003), 17051713.

[81] D.P. Bogdanos and D. Vergani, Bacteria and primary biliary cirrhosis, Clin Rev Allergy Immunol 36 (2009), 30-39.

[82] M.I. Prince, A. Chetwynd, P. Diggle, M. Jarner, J.V. Metcalf and O.F. James, The geographical distribution of primary biliary cirrhosis in a well-defined cohort, Hepatology 34 (2001), 1083-1088.

[83] A.C. Anand, E. Elias and J.M. Neuberger, End-stage primary biliary cirrhosis in a first generation migrant south asian population, Eur J Gastroenterol Hepatol 8 (1996), 663-666.

[84] I. Haruta, E. Hashimoto, Y. Kato, K. Kikuchi, H. Kato, J. Yagi, T. Uchiyama, M. Kobayash and K. Shiratori, Lipoteichoic acid may affect the pathogenesis of bile duct damage in primary biliary cirrhosis, Autoimmunity 39 (2006), 129-135.

[85] D.E. Jones, J.M. Palmer, A.D. Burt, C. Walker, A.J. Robe and J.A. Kirby. Bacterial motif DNA as an adjuvant for the breakdown of immune self-tolerance to pyruvate dehydrogenase complex, Hepatology 36 (2002), 679-686.

[86] R.Y. Lan, T.L. Salunga, K. Tsuneyama, Z.X. Lian, G.X. Yang, W. Hsu, Y. Moritoki, A.A. Ansari, C. Kemper, J. Price, J.P. Atkinson, R.L. Coppel and M.E. Gershwin, Hepatic il-17 responses in human and murine primary biliary cirrhosis, $J$ Autoimmun 32 (2009), 43-51.

[87] G. Rong, Y. Zhou, Y. Xiong, L. Zhou, H. Geng, T. Jiang, Y. Zhu, H. Lu, S. Zhang, P. Wang, B. Zhang and R. Zhong, Imbalance between $t$ helper type 17 and $t$ regulatory cells in patients with primary biliary cirrhosis: The serum cytokine profile and peripheral cell population, Clin Exp Immunol 156 (2009), 217-225. 
[88] K. Harada, S. Shimoda, Y. Sato, K. Isse, H. Ikeda and Y. Nakanuma, Periductal interleukin-17 production in association with biliary innate immunity contributes to the pathogenesis of cholangiopathy in primary biliary cirrhosis, Clin Exp Immunol 157 (2009), 261-270.

[89] J. Van de Water, H. Ishibashi, R.L. Coppel and M.E. Gershwin, Molecular mimicry and primary biliary cirrhosis: Premises not promises, Hepatology 33 (2001), 771-775.

[90] N. Agmon-Levin, B.S. Katz and Y. Shoenfeld, Infection and primary biliary cirrhosis, Isr Med Assoc J 11 (2009), 112115.

[91] T.K. Mao, Z.X. Lian, C. Selmi, Y. Ichiki, P. Ashwood, A.A Ansari, R.L. Coppel, S. Shimoda, H. Ishibashi and M.E. Gershwin, Altered monocyte responses to defined tlr ligands in patients with primary biliary cirrhosis, Hepatology 42 (2005), 802-808.

[92] O. Barzilai, M. Ram and Y. Shoenfeld, Viral infection can induce the production of autoantibodies, Curr Opin Rheumatol 19 (2007), 636-643.

[93] M.L. Santiago-Raber, I. Dunand-Sauthier, T. Wu, Q.Z. Li, S. Uematsu, S. Akira, W. Reith, C. Mohan, B.L. Kotzin and S. Izui, Critical role of tlr7 in the acceleration of systemic lupus erythematosus in tlr9-deficient mice, J Autoimmun 34 (2010), 339-348.

[94] J.D. Fraser and T. Proft, The bacterial superantigen and superantigen-like proteins, Immunol Rev 225 (2008), 226243.

[95] J. Czarneski, J.C. Rassa and S.R. Ross, Mouse mammary tumor virus and the immune system, Immunol Res 27 (2003), 469-480.

[96] R. Kuppers, B cells under influence: Transformation of b cells by epstein-barr virus, Nat Rev Immunol 3 (2003), 801812.

[97] F.L. van de Veerdonk, M.S. Gresnigt, B.J. Kullberg, J.W. van der Meer, L.A. Joosten and M.G. Netea, Th17 responses and host defense against microorganisms: An overview, $B M B$ Rep 42 (2009), 776-787.

[98] R.Y. Lan, C. Cheng, Z.X. Lian, K. Tsuneyama, G.X. Yang, Y. Moritoki, Y.H. Chuang, T. Nakamura, S. Saito, S. Shimoda, A. Tanaka, C.L. Bowlus, Y. Takano, A.A. Ansari, R.L. Coppel and M.E. Gershwin, Liver-targeted and peripheral blood alterations of regulatory $\mathrm{t}$ cells in primary biliary cirrhosis, Hepatology 43 (2006), 729-737.

[99] G.P. Morris, N.K. Brown and Y.C. Kong, Naturally-existing $\mathrm{cd} 4(+) \mathrm{cd} 25(+)$ foxp3(+) regulatory $\mathrm{t}$ cells are required for tolerance to experimental autoimmune thyroiditis induced by either exogenous or endogenous autoantigen, J Autoimmun 33 (2009), 68-76.

[100] R.E. Nickowitz and H.J. Worman, Autoantibodies from patients with primary biliary cirrhosis recognize a restricted region within the cytoplasmic tail of nuclear pore membrane glycoprotein gp210, J Exp Med 178 (1993), 2237-2242.

[101] I. Mayo, P. Arizti, A. Pares, J. Oliva, R.A. Doforno, M.R. de Sagarra, J. Rodes and J.G. Castano, Antibodies against the cooh-terminal region of e. Coli clpp protease in patients with primary biliary cirrhosis, J Hepatol 33 (2000), 528-536.

[102] H. Baum, D.P. Bogdanos and D. Vergani, Antibodies to clp protease in primary biliary cirrhosis: Possible role of a mimicking t-cell epitope, J Hepatol 34 (2001), 785-787.

[103] D.P. Bogdanos, H. Baum, U.C. Sharma, A. Grasso, Y. Ma, A.K. Burroughs and D. Vergani, Antibodies against homologous microbial caseinolytic proteases $\mathrm{p}$ characterise primary biliary cirrhosis, J Hepatol 36 (2002), 14-21.
[104] C. Selmi, D.L. Balkwill, P. Invernizzi, A.A. Ansari, R.L. Coppel, M. Podda, P.S. Leung, T.P. Kenny, J. Van De Water, M.H. Nantz, M.J. Kurth and M.E. Gershwin, Patients with primary biliary cirrhosis react against a ubiquitous xenobioticmetabolizing bacterium, Hepatology 38 (2003), 1250-1257.

[105] M.M. Kaplan, Novosphingobium aromaticivorans: A potential initiator of primary biliary cirrhosis, Am J Gastroenterol 99 (2004), 2147-2149.

[106] R. Stemerowicz, U. Hopf, B. Moller, C. Wittenbrink, A. Rodloff, R. Reinhardt, M. Freudenberg and C. Galanos, Are antimitochondrial antibodies in primary biliary cirrhosis induced by r(rough)-mutants of enterobacteriaceae? Lancet $\mathbf{2}$ (1988), 1166-1170.

[107] H. Kita, S. Matsumura, X.S. He, A.A. Ansari, Z.X. Lian, J. Van de Water, R.L. Coppel, M.M. Kaplan and M.E. Gershwin, Analysis of tcr antagonism and molecular mimicry of an hla-a0201-restricted ctl epitope in primary biliary cirrhosis, Hepatology 36 (2002), 918-926.

[108] I. Haruta, K. Kikuchi, E. Hashimoto, H. Kato, K. Hirota, M. Kobayashi, Y. Miyake, T. Uchiyama, J. Yagi and K. Shiratori, A possible role of histone-like DNA-binding protein of streptococcus intermedius in the pathogenesis of bile duct damage in primary biliary cirrhosis, Clin Immunol 127 (2008), 245-251.

[109] D.P. Bogdanos, H. Baum, M. Okamoto, P. Montalto, U.C. Sharma, E.I. Rigopoulou, J. Vlachogiannakos, Y. Ma, A.K. Burroughs and D. Vergani, Primary biliary cirrhosis is characterized by igg 3 antibodies cross-reactive with the major mitochondrial autoepitope and its lactobacillus mimic, Hepatology 42 (2005), 458-465.

[110] T.J. Sayers and H. Baum, Possible cross-reactivity of human anti-mitochondrial antibodies with membrane vesicles of paracoccus denitrificans, Biochem Soc Trans 4 (1976), $138-139$.

[111] G. Jan, M. Le Henaff, C. Fontenelle and H. Wroblewski, Biochemical and antigenic characterisation of mycoplasma gallisepticum membrane proteins p52 and p67 (pmga), Arch Microbiol 177 (2001), 81-90.

[112] C.P. Berg, T.R. Kannan, R. Klein, M. Gregor, J.B. Baseman, S. Wesselborg, K. Lauber and G.M. Stein, Mycoplasma antigens as a possible trigger for the induction of antimitochondrial antibodies in primary biliary cirrhosis, Liver Int $\mathbf{2 9}$ (2009), 797-809.

[113] D.P. Bogdanos, A. Pares, H. Baum, L. Caballeria, E.I. Rigopoulou, Y. Ma, A.K. Burroughs, J. Rodes and D. Vergani, Disease-specific cross-reactivity between mimicking peptides of heat shock protein of mycobacterium gordonae and dominant epitope of e 2 subunit of pyruvate dehydrogenase is common in spanish but not british patients with primary biliary cirrhosis, J Autoimmun 22 (2004), 353-362.

[114] D.P. Bogdanos, A. Koutsoumpas, H. Baum and D. Vergani, Borrelia burgdorferi: A new self-mimicking trigger in primary biliary cirrhosis, Dig Liver Dis 38 (2006), 781-782; author reply 782-783.

[115] P.N. Uzoegwu, H. Baum and J. Williamson, The occurrence and localization in trypanosomes and other endo-parasites of an antigen cross-reacting with mitochondrial antibodies of primary biliary cirrhosis, Comp Biochem Physiol B $\mathbf{8 8}$ (1987), 1181-1189.

[116] K. Harada, K. Tsuneyama, Y. Sudo, S. Masuda and Y. Nakanuma, Molecular identification of bacterial 16s ribosomal rna gene in liver tissue of primary biliary cirrhosis: Is propionibacterium acnes involved in granuloma formation? Hepatology 33 (2001), 530-536. 
[117] S.A. Morshed, M. Nishioka, I. Saito, K. Komiyama and I. Moro, Increased expression of epstein-barr virus in primary biliary cirrhosis patients, Gastroenterol Jpn 27 (1992), 751758.

[118] J. Mattner, P.B. Savage, P. Leung, S.S. Oertelt, V. Wang, O. Trivedi, S.T. Scanlon, K. Pendem, L. Teyton, J. Hart, W.M. Ridgway, L.S. Wicker, M.E. Gershwin and A. Bendelac, Liver autoimmunity triggered by microbial activation of natural killer t cells, Cell Host Microbe 3 (2008), 304-315.

[119] M.J. Goo, M.R. Ki, H.R. Lee, I.H. Hong, J.K. Park, H.J. Yang, D.W. Yuan, O.K. Hwang, S.H. Do, S.E. Yoo and K.S. Jeong, Primary biliary cirrhosis, similar to that in human beings, in a male c57bl/6 mouse infected with helicobacter pylori, Eur J Gastroenterol Hepatol 20 (2008), 1045-1048.

[120] G.J. Tobon, P. Youinou and A. Saraux, The environment, geo-epidemiology, and autoimmune disease: Rheumatoid arthritis, J Autoimmun 35 (2010), 10-14.

[121] C.L. Burek and M.V. Talor, Environmental triggers of autoimmune thyroiditis, J Autoimmun 33 (2009), 183-189.

[122] U. Christen, P. Jeno and J. Gut, Halothane metabolism: The dihydrolipoamide acetyltransferase subunit of the pyruvate dehydrogenase complex molecularly mimics trifluoroacetylprotein adducts, Biochemistry 32 (1993), 1492-1499.

[123] H.R. Walden, J.A. Kirby, S.J. Yeaman, J. Gray, D.E. Jones and J.M. Palmer, Xenobiotic incorporation into pyruvate dehydrogenase complex can occur via the exogenous lipoylation pathway, Hepatology 48 (2008), 1874-1884.

[124] R. Rieger, P.S. Leung, M.R. Jeddeloh, M.J. Kurth, M.H. Nantz, K.S. Lam, D. Barsky, A.A. Ansari, R.L. Coppel, I.R. Mackay and M.E. Gershwin, Identification of 2-nonynoic acid, a cosmetic component, as a potential trigger of primary biliary cirrhosis, J Autoimmun 27 (2006), 7-16.

[125] P.S. Leung, O. Park, K. Tsuneyama, M.J. Kurth, K.S. Lam, A.A. Ansari, R.L. Coppel and M.E. Gershwin, Induction of primary biliary cirrhosis in guinea pigs following chemical xenobiotic immunization, J Immunol 179 (2007), 26512657.

[126] K. Wakabayashi, K. Yoshida, P.S. Leung, Y. Moritoki, G.X. Yang, K. Tsuneyama, Z.X. Lian, T. Hibi, A.A. Ansari, L.S. Wicker, W.M. Ridgway, R.L. Coppel, I.R. Mackay and M.E. Gershwin, Induction of autoimmune cholangitis in non-obese diabetic (nod).1101 mice following a chemical xenobiotic immunization, Clin Exp Immunol 155 (2009), 577-586.

[127] K. Wakabayashi, Z.X. Lian, P.S. Leung, Y. Moritoki, K. Tsuneyama, M.J. Kurth, K.S. Lam, K. Yoshida, G.X. Yang, T. Hibi, A.A. Ansari, W.M. Ridgway, R.L. Coppel, I.R. Mackay and M.E. Gershwin, Loss of tolerance in c57bl/6 mice to the autoantigen e2 subunit of pyruvate dehydrogenase by a xenobiotic with ensuing biliary ductular disease, Hepatology (Baltimore, Md 48 (2008), 531-540.

[128] S.A. Long, C. Quan, J. Van de Water, M.H. Nantz, M.J. Kurth, D. Barsky, M.E. Colvin, K.S. Lam, R.L. Coppel, A. Ansari and M.E. Gershwin, Immunoreactivity of organic mimeotopes of the e 2 component of pyruvate dehydrogenase: Connecting xenobiotics with primary biliary cirrhosis, J Immunol 167 (2001), 2956-2963.

[129] P.S. Leung, C. Quan, O. Park, J. Van de Water, M.J. Kurth, M.H. Nantz, A.A. Ansari, R.L. Coppel, K.S. Lam and M.E. Gershwin, Immunization with a xenobiotic 6bromohexanoate bovine serum albumin conjugate induces antimitochondrial antibodies, J Immunol 170 (2003), 53265332.

[130] K. Amano, P.S. Leung, Q. Xu, J. Marik, C. Quan, M.J. Kurth, M.H. Nantz, A.A. Ansari, K.S. Lam, M. Zeniya, R.L. Coppel and M.E. Gershwin, Xenobiotic-induced loss of tolerance in rabbits to the mitochondrial autoantigen of primary biliary cirrhosis is reversible, J Immunol 172 (2004), 6444-6452.

[131] A. Lleo, P.M. Battezzati, C. Selmi, M.E. Gershwin and M. Podda, Is autoimmunity a matter of sex? Autoimmun Rev 7 (2008), 626-630.

[132] A. Parikh-Patel, E. Gold, J. Utts and M.E. Gershwin, The association between gravidity and primary biliary cirrhosis, Ann Epidemiol 12 (2002), 264-272.

[133] D. Bogdanos, T. Pusl, C. Rust, D. Vergani and U. Beuers, Primary biliary cirrhosis following lactobacillus vaccination for recurrent vaginitis, J Hepatol 49 (2008), 466-473.

[134] P. Invernizzi, M. Miozzo, P.M. Battezzati, I. Bianchi, F.R. Grati, G. Simoni, C. Selmi, M. Watnik, M.E. Gershwin and M. Podda, Frequency of monosomy $x$ in women with primary biliary cirrhosis, Lancet 363 (2004), 533-535.

[135] C. Selmi, The $x$ in sex: How autoimmune diseases revolve around sex chromosomes, Best Pract Res Clin Rheumatol 22 (2008), 913-922.

[136] Y. Svyryd, G.H. Molina, F. Vargas, J. Sanchez-Guerrero, D.A. Segovia and O.M. Mutchinick, X chromosome monosomy in primary and overlapping autoimmune diseases, $A u$ toimmun Rev (2010).

[137] P. Invernizzi, S. Pasini, C. Selmi, M.E. Gershwin and M. Podda, Female predominance and x chromosome defects in autoimmune diseases, J Autoimmun 33 (2009), 12-16.

[138] L. Persani, R. Rossetti, C. Cacciatore and M. Bonomi, Primary ovarian insufficiency: $\mathrm{X}$ chromosome defects and autoimmunity, J Autoimmun 33 (2009), 35-41.

[139] A.H. Sawalha, J.B. Harley and R.H. Scofield, Autoimmunity and klinefelter's syndrome: When men have two x chromosomes, J Autoimmun 33 (2009), 31-34.

[140] Y. Shapira, N. Agmon-Levin and Y. Shoenfeld, Defining and analyzing geoepidemiology and human autoimmunity, $J$ Autoimmun 34 (2010), J168-J177.

[141] Y. Shoenfeld, C. Selmi, E. Zimlichman and M.E. Gershwin, The autoimmunologist: Geoepidemiology, a new center of gravity, and prime time for autoimmunity, J Autoimmun $\mathbf{3 1}$ (2008), 325-330.

[142] G.S. Cooper, M.L. Bynum and E.C. Somers, Recent insights in the epidemiology of autoimmune diseases: Improved prevalence estimates and understanding of clustering of diseases, J Autoimmun 33 (2009), 197-207.

[143] P. Invernizzi, Geoepidemiology of autoimmune liver diseases, J Autoimmun 34 (2010), J300-J306.

[144] V. Chandran and S.P. Raychaudhuri, Geoepidemiology and environmental factors of psoriasis and psoriatic arthritis, $J$ Autoimmun 34 (2010), J314-J321.

[145] P. Youinou, J.O. Pers, M.E. Gershwin and Y. Shoenfeld, Geoepidemiology and autoimmunity, J Autoimmun 34 (2010), J163-J167.

[146] I. Sekigawa, M. Kawasaki, H. Ogasawara, K. Kaneda, H. Kaneko, Y. Takasaki and H. Ogawa, DNA methylation: Its contribution to systemic lupus erythematosus, Clin Exp Med 6 (2006), 99-106.

[147] P.S. Patole, R.D. Pawar, J. Lichtnekert, M. Lech, O.P. Kulkarni, A. Ramanjaneyulu, S. Segerer and H.J. Anders, Coactivation of toll-like receptor-3 and -7 in immune complex glomerulonephritis, J Autoimmun 29 (2007), 52-59.

[148] J.T. Salas, J.M. Banales, S. Sarvide, S. Recalde, A. Ferrer, I. Uriarte, R.P. Oude Elferink, J. Prieto and J.F. Medina, Ae2a,b-deficient mice develop antimitochondrial antibodies and other features resembling primary biliary cirrhosis, Gastroenterology 134 (2008), 1482-1493. 
[149] J.M. Palmer, A.J. Robe, A.D. Burt, J.A. Kirby and D.E. Jones, Covalent modification as a mechanism for the breakdown of immune tolerance to pyruvate dehydrogenase complex in the mouse, Hepatology (Baltimore, Md 39 (2004), 1583-1592.

[150] Y. Ueno, Y. Moritoki, T. Shimosegawa and M.E. Gershwin, Primary biliary cirrhosis: What we know and what we want to know about human pbc and spontaneous pbc mouse models, J Gastroenterol 42 (2007), 189-195.

[151] K.A. Padgett, R.Y. Lan, P.C. Leung, A. Lleo, K. Dawson, J. Pfeiff, T.K. Mao, R.L. Coppel, A.A. Ansari and M.E. Gershwin, Primary biliary cirrhosis is associated with altered hepatic microrna expression, J Autoimmun 32 (2009), 246253.

[152] L. Senolt, J. Vencovsky, K. Pavelka, C. Ospelt and S. Gay, Prospective new biological therapies for rheumatoid arthritis, Autoimmun Rev 9 (2009), 102-107.

[153] N.R. York, J.P. Mendoza, S.B. Ortega, A. Benagh, A.F. Tyler, M. Firan and N.J. Karandikar, Immune regulatory cns-reactive $\mathrm{cd} 8+\mathrm{t}$ cells in experimental autoimmune encephalomyelitis, J Autoimmun 35 (2010), 33-44.

[154] P.S. Leung, A. Dhirapong, P.Y. Wu and M.H. Tao, Gene therapy in autoimmune diseases: Challenges and opportunities, Autoimmun Rev 9 (2010), 170-174.

[155] D.P. Bogdanos, H. Baum, F. Gunsar, D. Arioli, D. Polymeros,
Y. Ma, A.K. Burroughs and D. Vergani, Extensive homology between the major immunodominant mitochondrial antigen in primary biliary cirrhosis and helicobacter pylori does not lead to immunological cross-reactivity, Scand J Gastroenterol 39 (2004), 981-987.

[156] P.S. Leung, O. Park, S. Matsumura, A.A. Ansari, R.L. Coppel and M.E. Gershwin, Is there a relation between chlamydia infection and primary biliary cirrhosis? Clin Dev Immunol 10 (2003), 227-233.

[157] J. O'Donohue, B. McFarlane, A. Bomford, M. Yates and R. Williams, Antibodies to atypical mycobacteria in primary biliary cirrhosis, J Hepatol 21 (1994), 887-889.

[158] W. Sakly, M. Jeddi and I. Ghedira, Anti-saccharomyces cerevisiae antibodies in primary biliary cirrhosis, Dig Dis Sci $\mathbf{5 3}$ (2008), 1983-1987.

[159] L. Xu, Z. Shen, L. Guo, B. Fodera, A. Keogh, R. Joplin, B. O'Donnell, J. Aitken, W. Carman, J. Neuberger and A. Mason, Does a betaretrovirus infection trigger primary biliary cirrhosis? Proc Natl Acad Sci U S A 100 (2003), 8454-8459.

[160] C. Selmi, S.R. Ross, A.A. Ansari, P. Invernizzi, M. Podda, R.L. Coppel and M.E. Gershwin, Lack of immunological or molecular evidence for a role of mouse mammary tumor retrovirus in primary biliary cirrhosis, Gastroenterology 127 (2004), 493-501. 


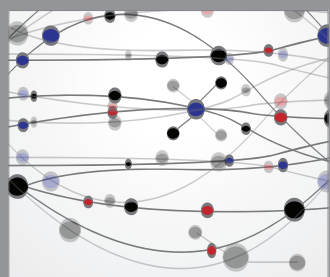

The Scientific World Journal
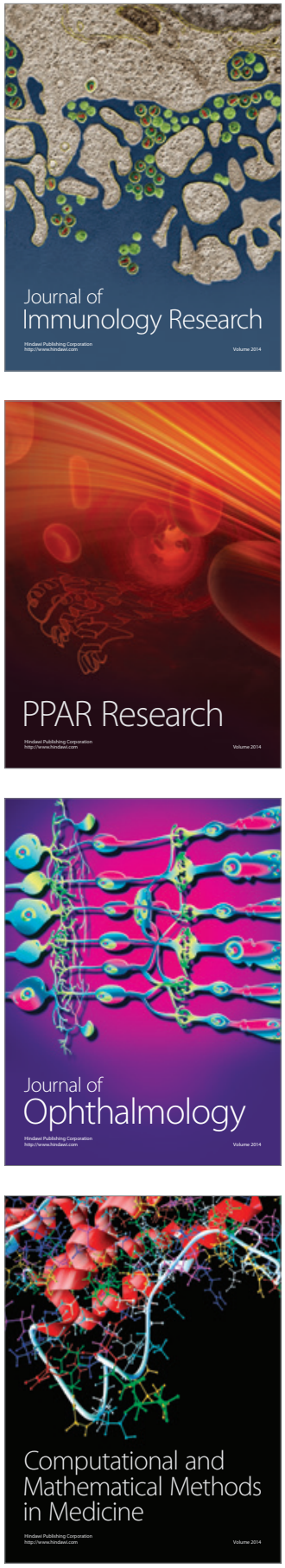

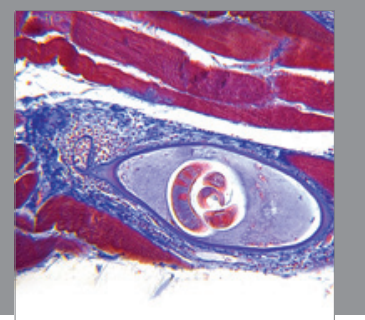

Gastroenterology

Research and Practice
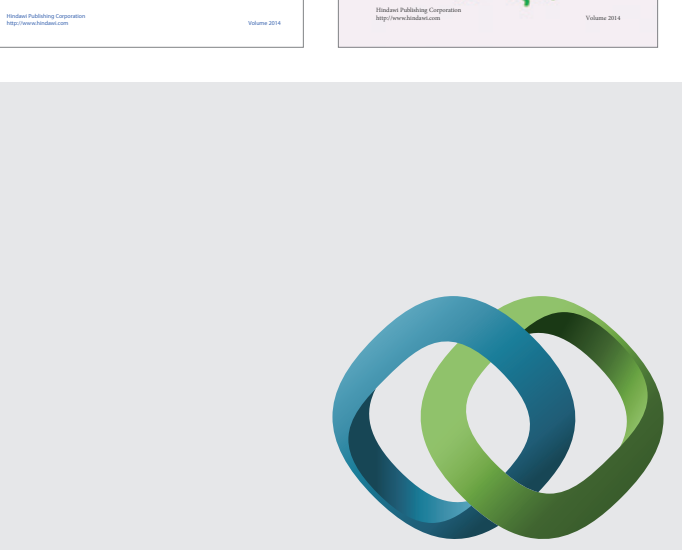

\section{Hindawi}

Submit your manuscripts at

http://www.hindawi.com
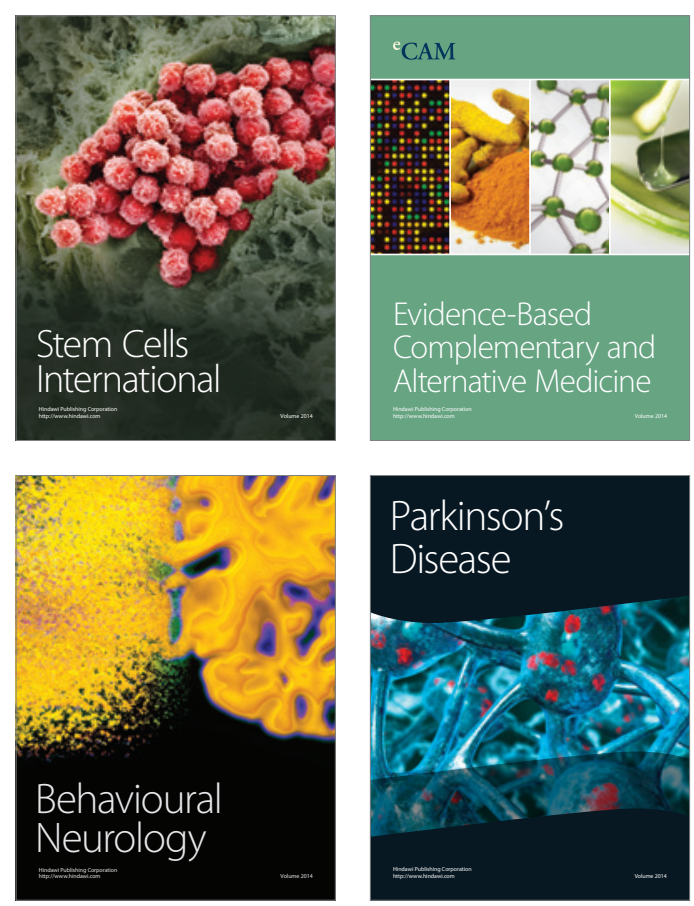

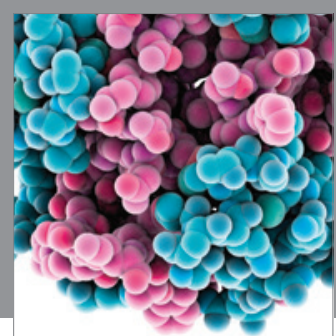

Journal of
Diabetes Research

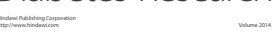

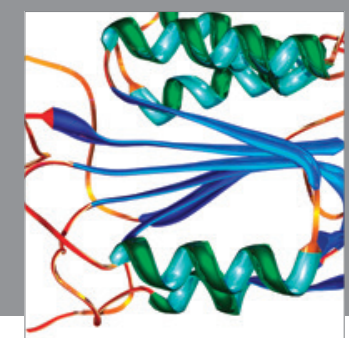

Disease Markers
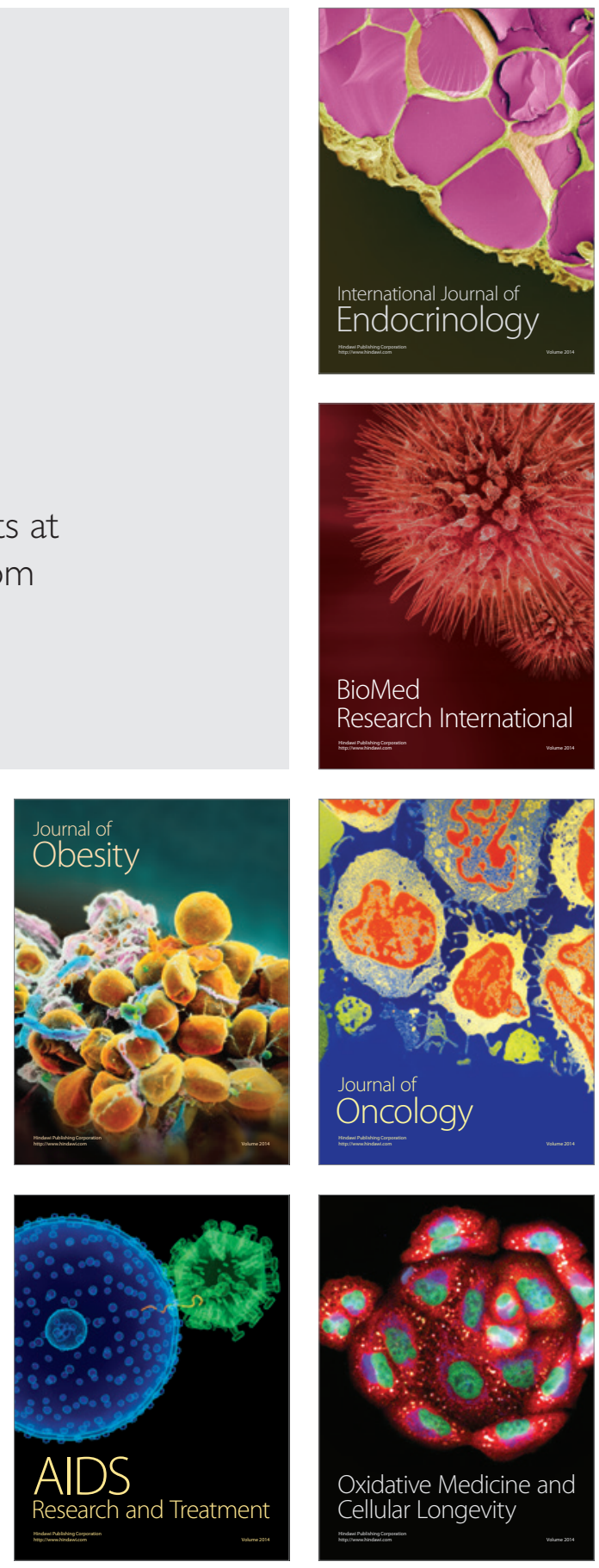